\title{
COMBINING ABILITY AND HERITABILITY FOR YIELD TRAITS IN WHEAT (Triticum aestivum $\mathbf{L}$.)
}

\author{
Muhammad Saeed ${ }^{1}$, Iftikhar Hussain Khalil ${ }^{1, *}$, Durr-e-Nayab ${ }^{1}$, Shakeel Ahmad Anjum ${ }^{2}$ and \\ Mohsin Tanveer ${ }^{2}$ \\ ${ }^{1}$ Department of Plant Breeding and Genetics, University of Agriculture, Peshawar, Pakistan; \\ ${ }^{2}$ Department of Agronomy, University of Agriculture, Faisalabad, Pakistan. \\ *Corresponding author's e-mail: drihkhalil@yahoo.com
}

\begin{abstract}
Six advance lines IR1, IR2, IR3, RF1, RF2 and RF3 and four cultivars Pirsabak-08 (PS08), Janbaz (JZ), Zam-04 (ZM04) and Kohat-10 (KT10) were crossed in line $\times$ testers fashion in spring 2011 to produce $F_{1}$ hybrids. The experimental material consisting of 34 genotypes ( 10 parents and $24 \mathrm{~F}_{1}$ hybrids) were evaluated under irrigated conditions in triplicated randomized complete block design at Cereal Crops Research Institute (CCRI), Pirsabak, Nowshera, Pakistan during 2011-12. Data were recorded on tillers plant ${ }^{-1}$, spike length, grains spike ${ }^{-1}, 1000$-grain weight, biological and grain yield plant ${ }^{-1}$. Mean of $24 \mathrm{~F}_{1}$ hybrids was greater than mean of 10 parents for all traits studied. Among lines RF3 and testers ZM-04 were good general combiners for most of the yield traits including grain yield plant ${ }^{-1}$. Cross combination RF3 $\times$ PS08 proved as good specific combiner showing positive SCA effects for all traits including grain yield plant ${ }^{-1}$. Crosses viz. IR1 $\times \mathrm{JZ}, \mathrm{RF} 2 \times \mathrm{ZM} 04$ and RF2 $\times$ KT10 proved as good specific combiners for all traits except 1000-grain weight. Another three set of crosses viz. IR $2 \times$ JZ, RF1 $\times$ KT10 and RF1 $\times$ JZ proved as good specific combiners for all traits except grains spike ${ }^{-1}$, biological yield and grain yield plant ${ }^{-1}$, respectively. All aforementioned crosses expected to yield transgressive segregants with more grain yield compared to their parents as these cross combinations had positive SCA effects for grain yield plant ${ }^{-1}$. GCA to SCA variances ratio revealed predominantly non-additive gene effects in the inheritance of all traits in wheat. Development of high yielding varieties with improved traits is therefore suggested through selection in late segregating generations.
\end{abstract}

Keywords: Wheat, yield components, line $\times$ testers analysis, non-additive gene effect, heritability.

\section{INTRODUCTION}

Wheat (Triticum aestivum L.) is a major food crop in Pakistan and of the world as well. During 2013-14, Pakistan produced 25.98 million tons wheat from 9.19 million hectares with an average yield of $2824 \mathrm{~kg} \mathrm{ha}^{-1}$ (MINNFSAR, 2015). However, geometrical increase in Pakistan population has been a challenge for agricultural scientists. To feed increasing population of Pakistan, there is a dire need to develop wheat genotypes with high yield potential. This could be achieved by combining together good attributes from available wheat germplasm into a single genotype (Khan et al., 2014).

Assessment of general combining ability (GCA) effects for yield components has great potential in selection of desirable parents (Bhateria et al., 2006). Highly productive wheat cultivars could be developed by crossing good general combining genotypes for grain yield and its components and selecting desirable segregants from resulting hybrid populations. Line $\times$ tester analysis is an evaluation technique, developed by Kempthrone (1957), which is a modified form of top cross scheme. In case of top cross only one tester is used, while in line $\times$ tester mating several testers are used. The first step in evaluating the potential of new lines is to cross them to a common parent (tester) and compare the performance of their hybrids (test crosses or top crosses).

Knowledge of general and specific combining abilities influencing yield and its components has become increasingly important to the plant breeders in order to select suitable parents for developing potential hybrids (Kruvadi, 1991). Many researchers have studied the combining ability and genetic structure of bread wheat hybrid populations using line $x$ tester method related to yield and yield components. It is reported that grain yield plant ${ }^{-1}$ and most of traits are under control of non-additive gene effect (Sulayman and Akguni, 2007). Several researchers (Larik et al., 1995; Akbar et al., 1997; Masood and Kronstad, 2000; Ahmadi et al., 2003; Joshi et al., 2003) have reported that majority of genetic variances of grain yield as well as yield components are under control of non-additive nature of genes. However, Akbar et al. (1997) have reported that numbers of tillers plant ${ }^{-1}$ is controlled by additive gene action.

This study was undertaken to find out good general combining lines and testers for important yield contributing traits, so that superior cross combination are selected for development of desirable wheat genotypes. 


\section{MATERIALS AND METHODS}

This research was carried out at Cereal Crops Research Institute (CCRI), Pirsabak, Nowshera, Pakistan. Six advanced wheat genotypes (hereafter referred to as lines) and four wheat cultivars (hereafter referred to as testers) were crossed in line $\times$ tester fashion during spring 2011. The six lines, four testers and resultant $24 \mathrm{~F}_{1}$ cross combinations were subsequently evaluated under irrigated condition during wheat season 2011-12. The six lines were BIVN11 (IR1), BVIN5 (IR2), BVIN12 (IR3), BRF3 (RF1), BRF1 (RF2) and BRF17 (RF3). The first three lines (IR1, IR2 and IR3) were selected on the basis of their good performance in micro-plots trials under irrigated conditions, while the last three lines (RF1, RF2 and RF3) were selected due to outstanding performance in micro-plots trials under rainfed conditions (Table 1). Cultivars Pirsabak-08 (PS08) and Janbaz (JZ) are recommended for irrigated, while Zam-04 (ZM04) and Kohat-10 (KT10) are recommended for rainfed areas of Khyber Pakhtunkhwa.

Table 1. List of wheat lines and testers with their pedigree crossed in line $\times$ tester fashion to develop $24 \mathrm{~F}_{1}$ hybrids.

\begin{tabular}{ll}
\hline \multicolumn{1}{c}{ Lines/Testers } & Pedigree \\
\hline I. Lines & \\
BIVN11 (IR1) & KAUZ//ALTAR84/AOS3/P. \\
BVIN5 (IR2) & KAUZ//ALTAR84/AOS/3MI. \\
BVIN12 (IR3) & REH/HARE//2*BCN/3/CROC-1. \\
BRF3 (RF1) & PIRSABAK.85/SALEEM.2000 \\
BRF1 (RF2) & KAGHAN.93/4/T-ARST//KAL. \\
BRF17 (RF3) & KATILA-11 \\
II. Testers & \\
Zam-04 ( ZM04) & KAUZ*2/OPATA/KAUZCRG732. \\
Kohat-10 (KT10) & ALTAR84/AESQ//ARROSA219. \\
Pirsabak-08 (PS08) & KAUZ/PASTORCNSS93B00025S. \\
Janbaz (JZ) & SERI*3//RL6010/4*YR/3/PASTOR \\
\hline
\end{tabular}

Development of $\boldsymbol{F}_{1}$ hybrids: The breeding material (lines and testers) was sown during Oct-Nov 2010 in four crossing blocks, each at 10 days interval, at CCRI, Pirsabak, Nowshera for making crosses in line $\times$ tester fashion. Ten days planting gape was used among crossing blocks to ensure optimum pollen availability and to be able to make as many crosses as possible. Two rows per genotype were planted in each crossing block. The row length was 2 meter, and plant to plant distance was $10 \mathrm{~cm}$. Twenty to thirty good looking spikes were emasculated in each line and subsequently pollinated by a specific tester in each cross combinations to get required number of $F_{1}$ seed.

Field evaluation of parents and $F_{1}$ hybrids: The experimental material consisting of 34 genotypes (10 parents and $24 \mathrm{~F}_{1}$ hybrids) was sown in $1^{\text {st }}$ week of November, 2011 in triplicate randomized complete block design in two rows of
3 meter length at CCRI, Pirsabak. Spacing between plants and rows was kept as 10 and $30 \mathrm{~cm}$, respectively. A pre sowing irrigation was given 20 days before sowing to ensure proper moisture at sowing for better germination. The experimental field was well prepared and recommended dose of NP fertilizer @ 120:60 $\mathrm{kg} \mathrm{ha}^{-1}$ was applied to the field. Standard cultural practices were adopted throughout growing season.

Data recording and statistical analysis: Observation were recorded on ten mature guarded plants per genotype per replication for tillers plant ${ }^{-1}$, spike length, grains spike ${ }^{-1}$, 1000 -grain weight, grain and biological yield plant ${ }^{-1}$. The data were statistically analyzed using method of Jan et al. (2009). Data for traits showing significant differences were further analyzed using line $\times$ tester procedure of Kempthorne (1957). Narrow and broad sense heritability were computed using the additive, dominance and environmental variances computed from line $\times$ tester analysis (Bhateria et al., 2006) as follows; Broad-sense heritability $\left(\mathrm{h}^{2}{ }_{\mathrm{BS}}\right)=\mathrm{V}_{\mathrm{g}} / \mathrm{V}_{\mathrm{P}}$, Narrow-sense heritability $\left(h^{2}{ }_{N S}\right)=V_{A} / V_{P}$, whereas, $V_{A}=$ Additive variance, $\mathrm{V}_{\mathrm{g}}=$ Genetic variance, $\mathrm{V}_{\mathrm{P}}=$ Phenotypic variance

\section{RESULTS AND DISCUSSION}

Genetic variation and heritability estimates: Analysis of variance showed that genotypes were significantly different for all yield and its component traits (Table 2). The crosses ( $\mathrm{F}_{1}$ hybrids) also showed highly significant genetic variation for tillers plant ${ }^{-1}(\mathrm{P} \leq 0.01)$, spike length $(\mathrm{P} \leq 0.01)$, grains spike $^{-1}(\mathrm{P} \leq 0.01), 1000$-grain weight $(\mathrm{P} \leq 0.01)$, grain yield $\operatorname{plant}^{-1}(\mathrm{P} \leq 0.01)$ and biological yield $\operatorname{plant}^{-1}(\mathrm{P} \leq 0.01)$. The testers exhibited highly significant differences for all traits except grain spike ${ }^{-1}$. Similar trend of high genetic differences were also observed among parents for all yield traits. Parents vs crosses ( $F_{1}$ hybrids) contrast, which is comparison of overall mean of parents and hybrids, was also significant for all traits. Estimates of variances due to specific combining ability $\left(\sigma^{2}\right.$ sca $)$ and general combining ability $\left(\sigma^{2}\right.$ gca $)$ and their ratio revealed that $\sigma^{2}$ gca was greater than $\sigma^{2}$ sca for all the traits indicating the predominant role of non-additive gene action in the inheritance of all the traits of wheat. The maximum broad-sense heritability $\left(\mathrm{h}^{2}{ }_{\mathrm{B} . \mathrm{S}}\right)$ was observed for biological yield plant ${ }^{-1}(0.98)$ followed by grain yield $(0.96)$, 1000-grain weight (0.89) and grains spike ${ }^{-1}(0.81)$ (Table 3$)$. Greater heritability estimates indicate comparatively greater selection effectiveness for these important traits. Broad-sense heritability values for spike length $(0.73)$ and tillers plant ${ }^{-1}$ were moderate in magnitude. Maximum narrow sense heritability value was for 1000 -grain weight $(0.55)$ followed by grain yield plant ${ }^{-1}(0.48)$ and biological yield plant ${ }^{-1}(0.35)$. The present study revealed moderate to high level of heritability for 1000-grains weight suggesting that environmental effects accounted for minor portion of total 
Table 2. Mean squares for grain yield and its components in line $\times$ tester analysis under irrigated environment.

\begin{tabular}{|c|c|c|c|c|c|c|c|}
\hline S.O.V. & D.F & $\begin{array}{l}\text { Tillers } \\
\text { plant }^{-1}\end{array}$ & $\begin{array}{l}\text { Spike } \\
\text { length }\end{array}$ & $\begin{array}{l}\text { Grains } \\
\text { spike }^{-1}\end{array}$ & $\begin{array}{c}\text { 1000-grain } \\
\text { Weight }\end{array}$ & $\begin{array}{c}\text { Grain yield } \\
\text { plant }^{-1}\end{array}$ & $\begin{array}{c}\text { Biological yield } \\
\text { plant }^{-1}\end{array}$ \\
\hline Genotypes & 33 & $16.8 * *$ & $1.32 * *$ & $113.68 * *$ & $49.5 * *$ & $65.35 * *$ & $615.50 * *$ \\
\hline Parents & 9 & $8.4 * *$ & $1.14 * *$ & $147.30 * *$ & $73.9 * *$ & $6.31 * *$ & $116.89 * *$ \\
\hline Crosses & 23 & $13.1 * *$ & $1.37 * *$ & $86.81 * *$ & $39.8 * *$ & $86.89 * *$ & $549.18 * *$ \\
\hline Parents vs crosses & 1 & $175.5 * *$ & $1.70 * *$ & $428.93 *$ & $54.0 * *$ & $101.46^{* *}$ & $6628.13^{* *}$ \\
\hline Lines & 5 & $16.2 * *$ & $1.98 * *$ & $107.92 * *$ & $10.9 * *$ & $195.92 * *$ & $439.46 * *$ \\
\hline Testers & 3 & $16.7 * *$ & $0.95 * *$ & $149.87 * *$ & $182.5 * *$ & $113.81 * *$ & $1473.05 * *$ \\
\hline $\mathrm{L} \times \mathrm{T}$ & 15 & $11.4 * *$ & $1.25 * *$ & $67.16 * *$ & $20.9 * *$ & $45.16 * *$ & $400.98 * *$ \\
\hline Error & 66 & 2.35 & 0.16 & 6.58 & 1.91 & 1.16 & 3.97 \\
\hline Variance due to GCA & & 0.34 & 0.04 & 4.12 & 3.68 & 7.31 & 37.01 \\
\hline Variance due to SCA & & 3.01 & 0.36 & 20.19 & 6.26 & 14.66 & 132.34 \\
\hline GCA/SCA var. ratio & & 0.11 & 0.10 & 0.20 & 0.58 & 0.45 & 0.28 \\
\hline $\mathrm{CV}(\%)$ & & 12.85 & 3.69 & 4.45 & 2.74 & 5.12 & 3.31 \\
\hline
\end{tabular}

$*, * *=$ Significant at 5 and $1 \%$ probability level, respectively.

Table 3. Additive variances $\left(\sigma^{2} a\right)$, dominance variances $\left(\sigma^{2} \mathrm{D}\right)$, environmental variances $\left(\sigma^{2} \mathrm{e}\right)$ and heritability for various traits of 34 wheat genotypes evaluated under irrigated environment.

\begin{tabular}{lccccc}
\hline \multirow{2}{*}{ Traits } & \multicolumn{3}{c}{ Variances } & \multicolumn{2}{c}{ Heritability } \\
\cline { 2 - 6 } & $\boldsymbol{\sigma}^{\mathbf{2}} \mathbf{a}$ & $\boldsymbol{\sigma}^{\mathbf{2}} \mathbf{D}$ & $\boldsymbol{\sigma}^{\mathbf{2}} \mathbf{e}$ & $\mathbf{h}^{\mathbf{2}} \mathbf{\text { BS }}$ & $\mathbf{h}^{\mathbf{2}} \mathbf{\text { NS }}$ \\
\hline Tillers plant $^{-1}$ (no) & 0.68 & 3.01 & 2.35 & 0.61 & 0.11 \\
Spike length (cm) & 0.07 & 0.36 & 0.16 & 0.73 & 0.12 \\
Grains spike $^{-1}$ (no) & 8.23 & 20.19 & 6.58 & 0.81 & 0.24 \\
1000-grain weight $_{\text {Grain yield plant }^{-1}(\mathrm{~g})}$ & 10.10 & 6.26 & 1.91 & 0.89 & 0.55 \\
Biological yield plant $^{-1}$ (g) & 14.63 & 14.66 & 1.16 & 0.96 & 0.48 \\
\hline
\end{tabular}

phenotypic variation. Moderate to high heritability ranges have also been reported earlier by Noorka et al. (2014) in wheat by investigating and comparing common physiological and yield traits under irrigated condition. Low narrow sense heritability in case of tillers plant ${ }^{-1}$ and spike length suggests non-fixable components of variation governing these traits. Moderate to high range of heritability estimates for spike length have been reported by Khan et al. (2003) in $\mathrm{F}_{2}$ population of six cross combinations indicating greater magnitude of heritability with greater genetic advance for yield and other agronomic characters. High heritability estimates grain yield plant ${ }^{-1}$ have also been reported by Khan et al. (2010). In contrast, moderate narrow sense heritability in case of grains spike and tillers plant ${ }^{-1}$ indicated that these traits can be improved by making selections among recombinants. Since, gene action involved in crosses was non-additive type with high heritability; such crosses can be exploited in subsequent generations for isolating desirable segregants. Similar reports are published earlier by Khan et al. (2007), who found medium to low selection response for grains spike ${ }^{-1}$ in bread wheat.

Yield comparison of 34 wheat lines under irrigated environment: Mean value of the data showed that the performance of $F_{1}$ hybrids was comparatively better than of parents for tillers plant ${ }^{-1}$ (13 vs 10$)$, spike length (11.0 vs 10.8 $\mathrm{cm}$ ), grains $\operatorname{spike}^{-1}$ (58 vs 55), 1000-grain weight (52.0 vs $50.5 \mathrm{~g}$ ), grain yield (24 vs $19 \mathrm{~g} \mathrm{plant}^{-1}$ ) and biological yield (65 vs 48 g plant $^{-1}$ ) (Table 4).
General combining ability studies: The results for GCA effects of various yield contributing traits are presented in Table 5. Estimates of general combining ability effects were partitioned for lines and testers for the characters under study to search out potential parents for subsequent wheat breeding. Numbers of tillers plant ${ }^{-1}$ has key role in grain yield improvement. Positive GCA effect for tillers plant ${ }^{-1}$ were shown by lines IR1, IR3, RF2, RF3 and tester ZM04. Majeed et al. (2011) also reported positive GCA effects for tillers production in wheat parental lines under irrigated condition. Similarly, spike length is an important yield enhancing component. Three of the six lines and two testers showed positive GCA effect for spike length. Possible GCA effects for spike length have been reported by Akbar et al. (2009). 1000-grain weight is an important character contributing towards grain yield. Four lines (IR3, RF1, RF2 and RF3) along with two testers (ZM04 and KT10) showed positive general combining ability for 1000-grain weight. Parental lines IR1, RF3 and ZM04 proved as best general combiners for grain yield plant ${ }^{-1}$ and most of others important yield components traits. These parents also contributed a large number of favorable genes for high grain yield and other yield traits. Jatav et al. (2014) suggested that lines with high GCA values for important trait like grain yield should be used in future breeding programs to improve wheat yield. There was change in trend of lines for general combining ability effects of traits. For example, line IR1 and IR3 were good combiners for grains spike ${ }^{-1}$ and tillers plant ${ }^{-1}$, respectively. Among the lines, RF3 was good general combiner for all yield traits 
Table 4. Mean of 34 wheat genotypes for yield and its components under irrigated environment.

\begin{tabular}{|c|c|c|c|c|c|c|}
\hline Genotypes & $\begin{array}{l}\text { Tillers } \\
\text { plant }^{-1}\end{array}$ & $\begin{array}{c}\text { Spike } \\
\text { length }(\mathrm{cm})\end{array}$ & $\begin{array}{l}\text { Grains } \\
\text { spike }^{-1}\end{array}$ & $\begin{array}{c}\text { 1000-Grain } \\
\text { weight }(\mathrm{g})\end{array}$ & $\begin{array}{c}\text { Grain yield } \\
\text { plant }^{-1}(\mathrm{~g})\end{array}$ & $\begin{array}{c}\text { Biological yield } \\
\text { plant }^{-1}(\mathrm{~g})\end{array}$ \\
\hline \multicolumn{7}{|l|}{ Parents } \\
\hline IR1 & 9 & 10.0 & 60 & 45.3 & 20 & 45 \\
\hline IR2 & 7 & 11.1 & 59 & 54.0 & 18 & 44 \\
\hline IR3 & 8 & 11.0 & 53 & 45.1 & 13 & 37 \\
\hline RF1 & 11 & 11.4 & 43 & 48.3 & 17 & 52 \\
\hline RF2 & 12 & 11.6 & 46 & 47.7 & 22 & 51 \\
\hline RF3 & 11 & 10.0 & 55 & 51.2 & 19 & 42 \\
\hline ZM04 & 10 & 10.5 & 48 & 57.7 & 19 & 50 \\
\hline KT10 & 10 & 11.0 & 64 & 52.9 & 20 & 57 \\
\hline PS08 & 11 & 9.9 & 62 & 44.7 & 19 & 45 \\
\hline $\mathrm{JZ}$ & 11 & 11.0 & 55 & 57.5 & 20 & 55 \\
\hline Parent Mean & 10 & 10.8 & 55 & 50.5 & 19 & 48 \\
\hline \multicolumn{7}{|l|}{$\mathrm{F}_{\mathrm{I}}$ Hybrids } \\
\hline IR1× ZM04 & 13 & 108 & 56 & 57.8 & 23 & 64 \\
\hline $\mathrm{IR} 1 \times \mathrm{KT} 10$ & 13 & 9.5 & 57 & 51.5 & 34 & 81 \\
\hline IR1× PS08 & 13 & 10.9 & 62 & 46.2 & 25 & 60 \\
\hline IR1× JZ & 12 & 10.6 & 75 & 46.2 & 27 & 79 \\
\hline IR2× ZM04 & 12 & 10.9 & 59 & 51.7 & 24 & 64 \\
\hline IR2× KT10 & 10 & 10.9 & 64 & 54.4 & 23 & 64 \\
\hline IR2× PS08 & 9. & 10.5 & 63 & 48.8 & 17. & 46 \\
\hline IR2× JZ & 10 & 10.6 & 51 & 51.5 & 19 & 56 \\
\hline IR3× ZM04 & 18 & 12.9 & 58 & 52.4 & 29 & 77 \\
\hline IR3× KT10 & 10 & 10.8 & 41 & 55.9 & 16 & 42 \\
\hline IR3× PS08 & 12 & 11.0 & 57 & 47.3 & 19 & 49 \\
\hline IR3× JZ & 14 & 11.1 & 44 & 52.5 & 25 & 68 \\
\hline RF1× ZM04 & 11 & 10.5 & 57 & 54.1 & 24 & 80 \\
\hline $\mathrm{RF} 1 \times \mathrm{KT} 10$ & 14 & 11.0 & 67 & 59.7 & 26 & 76 \\
\hline RF1× PS08 & 13 & 10.9 & 53 & 46.0 & 27 & 61 \\
\hline RF1×JZ & 12 & 11.5 & 64 & 52.1 & 20 & 71 \\
\hline RF2× ZM04 & 16 & 12.0 & 61 & 53.8 & 36 & 87 \\
\hline $\mathrm{RF} 2 \times \mathrm{KT} 10$ & 16 & 12.0 & 58 & 54.9 & 29 & 86 \\
\hline RF2× PS08 & 11 & 11.3 & 59 & 50.6 & 12 & 39 \\
\hline $\mathrm{RF} 2 \times \mathrm{JZ}$ & 12 & 10.3 & 53 & 52.3 & 19 & 57 \\
\hline RF3× ZM04 & 15 & 11.0 & 58 & 50.2 & 29 & 75 \\
\hline $\mathrm{RF} 3 \times \mathrm{KT} 10$ & 12 & 11.0 & 54 & 57.3 & 28 & 70 \\
\hline RF3× PS08 & 14 & 11.9 & 62 & 50.3 & 27 & 66 \\
\hline RF3× JZ & 11 & 11.0 & 65 & 51.7 & 21 & 44 \\
\hline$F_{1}$ Mean & 13 & 11.0 & 58 & 52.0 & 24 & 65 \\
\hline $\operatorname{LSD}_{(0.05)}$ & 2.5 & 0.64 & 13.4 & 2.25 & 11.2 & 27.1 \\
\hline
\end{tabular}

except biological yield plant ${ }^{-1}$ followed by RF2. Similarly, RF1 was good general combiner for all traits except tillers plant $^{-1}$ and spike length. Performance of $\mathrm{F}_{1}$ hybrids was comparatively better than of Among testers, ZM04 was good general combiner for tillers plant ${ }^{-1}$, spike length, grain and biological yield, while PS08 and KT10 were good general combiners for grains spike $^{-1}$ and 1000-grain weight, respectively (Table 5).
Specific combining ability studies: The results for SCA effects of various yield contributing traits are presented in Table 6. Numbers of tillers plant ${ }^{-1}$ is an important yield contributing character. Specific combining ability effects were positive in more than $50 \% \quad \mathrm{~F}_{1}$ crosses. Cross combination RF3 $\times$ PS08 proved as good specific combiner showing positive SCA effects for all traits including grain yield plant ${ }^{-1}$ (Table 6 ). Crosses viz. IR3 $\times$ JZ, IR1 $\times$ JZ, RF2 $\times$ ZM04 and RF $2 \times$ KT10 proved as good specific combiners for all traits except 1000-grain weight. Another three set of 
Table 5. General combining ability effects of six lines and four testers in wheat under irrigated environment.

\begin{tabular}{|c|c|c|c|c|c|c|}
\hline Lines/testers & $\begin{array}{l}\text { Tillers } \\
\text { plant }^{-1}\end{array}$ & $\begin{array}{l}\text { Spike } \\
\text { length }\end{array}$ & $\begin{array}{l}\text { Grains } \\
\text { spike }^{-1}\end{array}$ & $\begin{array}{c}\text { 1000-grain } \\
\text { weight }\end{array}$ & $\begin{array}{c}\text { Grain yield } \\
\text { plant }^{-1}\end{array}$ & $\begin{array}{c}\begin{array}{c}\text { Biological yield } \\
\text { plant }^{-1}\end{array} \\
\end{array}$ \\
\hline \multicolumn{7}{|l|}{ I. Lines } \\
\hline IR1 & 0.14 & -0.59 & 4.13 & -1.62 & 3.06 & 6.06 \\
\hline IR2 & -2.14 & -0.33 & 1.11 & -0.47 & -3.36 & -7.44 \\
\hline IR3 & 0.86 & 0.42 & -7.99 & 0.00 & -1.86 & -6.28 \\
\hline RF1 & -0.32 & -0.05 & 1.96 & 0.92 & 0.06 & 6.89 \\
\hline RF2 & 1.09 & 0.39 & -0.57 & 0.86 & 0.14 & 2.06 \\
\hline RF3 & 0.36 & 0.16 & 1.38 & 0.31 & 1.97 & -1.28 \\
\hline \multicolumn{7}{|l|}{ II. Testers } \\
\hline ZM04 & 1.41 & 0.30 & 0.03 & 1.30 & 3.36 & 9.33 \\
\hline KT10 & -0.17 & -0.2 & -1.27 & 3.58 & 1.81 & 4.78 \\
\hline PS08 & -0.52 & 0.10 & 0.94 & -3.86 & -2.86 & -11.61 \\
\hline $\mathrm{JZ}$ & -0.72 & -0.2 & 0.31 & -1.02 & -2.31 & -2.50 \\
\hline SE of GCA for lines & 0.44 & 0.11 & 19.30 & 2.04 & 1.99 & 4.79 \\
\hline SE of GCA for tester & 0.36 & 0.09 & 15.70 & 1.66 & 1.63 & 3.91 \\
\hline
\end{tabular}

Table 6. Specific combining ability effects of $24 \mathrm{~F}_{1}$ crosses derived from six lines and four testers in wheat under irrigated environment.

\begin{tabular}{|c|c|c|c|c|c|c|}
\hline F $_{1}$ Crosses & $\begin{array}{l}\text { Tillers } \\
\text { plant }^{-1}\end{array}$ & $\begin{array}{l}\text { Spike } \\
\text { length }\end{array}$ & $\begin{array}{l}\text { Grains } \\
\text { spike }^{-1}\end{array}$ & $\begin{array}{c}\text { 1000-grain } \\
\text { weight }\end{array}$ & $\begin{array}{c}\text { Grain yield } \\
\text { plant }^{-1}\end{array}$ & $\begin{array}{c}\text { Biological } \\
\text { yield plant }{ }^{-1}\end{array}$ \\
\hline IR1×ZM04 & -0.99 & 0.02 & -6.39 & 6.10 & -7.11 & -16.50 \\
\hline IR1×KT10 & -0.01 & -0.73 & -3.76 & -2.48 & 4.78 & 5.06 \\
\hline IR1×PS08 & 0.93 & 0.38 & -1.77 & -0.37 & 0.44 & 0.78 \\
\hline $\mathrm{IR} 1 \times \mathrm{JZ}$ & 0.07 & 0.34 & 11.92 & -3.25 & 1.89 & 10.7 \\
\hline IR2× ZM04 & 0.49 & -0.14 & -0.242 & -1.15 & -0.36 & -2.67 \\
\hline IR $2 \times$ KT10 & -0.19 & 0.35 & 5.66 & -0.80 & 0.19 & 1.89 \\
\hline IR2× PS08 & -0.72 & -0.28 & 3.11 & 1.04 & -0.81 & -0.39 \\
\hline IR2× JZ & 0.42 & 0.08 & -8.53 & 0.90 & 0.97 & 1.17 \\
\hline IR3× ZM04 & 2.69 & 1.13 & 7.79 & -0.91 & 3.14 & 9.17 \\
\hline IR3× KT10 & -3.06 & -0.51 & -7.51 & 0.30 & -7.97 & -21.94 \\
\hline IR3× PS08 & -1.05 & -0.48 & 5.81 & -0.89 & 0.03 & 1.44 \\
\hline IR3×JZ & 1.42 & -0.15 & -6.10 & 1.50 & 4.81 & 11.33 \\
\hline RF1× ZM04 & -3.12 & -0.79 & -2.96 & -0.17 & -3.78 & -1.67 \\
\hline RF1× KT10 & 1.32 & 0.20 & 8.28 & 3.180 & 0.11 & -0.44 \\
\hline RF1× PS08 & 1.53 & -0.10 & -8.40 & -3.12 & 5.44 & 0.61 \\
\hline $\mathrm{RF} 1 \times \mathrm{JZ}$ & 0.27 & 0.70 & 3.09 & 0.11 & -1.78 & 1.50 \\
\hline RF2× ZM04 & 0.66 & 0.30 & 3.51 & -0.41 & 8.81 & 10.17 \\
\hline $\mathrm{RF} 2 \times \mathrm{KT} 10$ & 2.64 & 0.79 & 1.54 & -1.60 & 3.03 & 13.72 \\
\hline $\mathrm{RF} 2 \times \mathrm{PS} 08$ & -2.55 & -0.14 & 0.06 & 1.58 & -8.97 & -16.56 \\
\hline $\mathrm{RF} 2 \times \mathrm{JZ}$ & -0.75 & -0.95 & -5.11 & 0.43 & -2.86 & -7.33 \\
\hline RF3× ZM04 & 0.26 & -0.53 & -1.71 & -3.46 & -0.69 & 1.50 \\
\hline $\mathrm{RF} 3 \times \mathrm{KT} 10$ & -0.69 & -0.08 & -4.21 & 1.39 & -0.14 & 1.72 \\
\hline RF3× PS08 & 1.85 & 0.63 & 1.18 & 1.76 & 3.86 & 14.11 \\
\hline $\mathrm{RF} 3 \times \mathrm{JZ}$ & -1.42 & -0.01 & 4.74 & 0.32 & -3.03 & -17.33 \\
\hline $\mathrm{SE}$ (SCA effect) & 0.88 & 0.23 & 38.55 & 4.07 & 3.98 & 9.59 \\
\hline $\mathrm{SE}(\mathrm{Gi}-\mathrm{Gj})$ for lines & 0.18 & 0.05 & 7.87 & 0.83 & 0.81 & 1.96 \\
\hline $\mathrm{SE}(\mathrm{Gi}-\mathrm{Gj})$ for testers & 0.12 & 0.03 & 5.25 & 0.55 & 0.54 & 1.31 \\
\hline SE ( Sij ) & 0.72 & 0.19 & 31.47 & 3.32 & 3.25 & 7.83 \\
\hline
\end{tabular}

crosses viz. IR2 $\times \mathrm{JZ}, \mathrm{RF} 1 \times \mathrm{KT} 10$ and $\mathrm{RF} 1 \mathrm{x} \mathrm{JZ}$ were good specific combiners for all traits except grains spike-1, biological yield and grain yield plant ${ }^{-1}$, respectively. All above mentioned crosses (except RF1 $\times$ JZ) expected to yield transgressive segregants with more grain yield compared to their parents as these cross combinations had positive SCA effect for grain yield plant ${ }^{-1}$. Among the crosses, IR1 $\times$ PS08 showed good SCA effect for most traits except grains spike ${ }^{-1}$ 
and 1000-grain weight, while IR2 $\times$ KT10 was poor specific combiner for tillers plant ${ }^{-1}$ and 1000 -grain weight. Similarly, IR3 $\times$ JZ showed poor SCA effects for spike length and grains spike $^{-1}$ (Table 6). The $\mathrm{F}_{1}$ cross combinations IR3 $\times$ ZM04, IR3 $\times \mathrm{JZ}, \mathrm{RF} 1 \times \mathrm{KT} 10, \mathrm{RF} 1 \times \mathrm{PS} 08, \mathrm{RF} 2 \times \mathrm{KT} 10$ and RF3 $\times$ PS0 8 exhibited positive SCA effects for tillers plant ${ }^{-1}$. The best cross was IR3 $\times$ ZM04 with the highest SCA value of 2.69 followed by RF $2 \times$ KT10 with SCA of 2.64. These results are in the agreement with those of Majeed et al. (2011), Sarkar et al. (1987), and Chaudhry et al. (1992) who observed positive SCA for tillers plant ${ }^{-1}$ in their studies. Similarly, for spike length $45 \%$ crosses showed positive response in terms of specific combining ability effects. The cross IR3 $\times$ ZM04 appeared to be best specific combiner with the value of 1.13. Similar results were observed by Akbar et al. (2009) who observed that more than $60 \%$ crosses showed positive SCA effect for grain yield plant $^{-1}$. About $65 \%$ crosses showed positive specific combining ability for 1000-grain weight. Among $\mathrm{F}_{1}$ crosses, IR $1 \times \mathrm{ZM} 04$ showed highest value of SCA for 1000-grain weight, followed by crosses RF3 $\times$ PS08 and RF2 $\times$ PS08 indicating non-additive gene effects. Similar findings were reported by Corral (1983) and Chaudhry et al. (1992).

The $\mathrm{F}_{1}$ cross $\mathrm{RF} 2 \times \mathrm{ZM} 04$ appeared as best and most promising specific combiner for grain yield plant ${ }^{-1}$ followed by $\mathrm{F}_{1}$ crosses $\mathrm{RF} 1 \times \mathrm{PS} 08, \mathrm{IR} 3 \times \mathrm{JZ}$ and IR $1 \times \mathrm{KT} 10$. These crosses showed significant positive SCA effects for grain
$F_{2}$ and $F_{3}$ ) obtained by crossing these parents will release hidden genetic variability through breakage of undesirable linkages involved in different characters. It may produce an elite population for selection of high yielding lines in advanced generations.

Contribution of lines, testers and their interactions towards yield testing: The proportional contribution of lines, testers and their interactions to total variances for different traits revealed that maximum contribution to total variance of tillers plant $^{-1}$, spike length, grains spike ${ }^{-1}$, grain yield plant ${ }^{-1}$ and biological yield plant $^{-1}$ was due to line $\times$ tester interaction effect, while testers contributed higher for 1000-grain weight. Moreover, lines showed more contribution than testers for tillers plant ${ }^{-1}$, spike length and grains spike ${ }^{-1}$. In contrast, testers had more contribution for 1000-grain weight, grain yield and biological yield plant ${ }^{-1}$ (Table 7).

Conclusion: Low narrow-sense heritability coupled with low GCA effects as compared with SCA effects were observed for tiller plant ${ }^{-1}$, spike length, grain spike ${ }^{-1}$ and biological yield plant $^{-1}$. Both GCA and SCA effect were found significant along with moderate narrow sense heritability for 1000-grain weight and grain yield. Line RF3 and tester ZM-04 were best general combiners for various traits especially for yield and associated traits, while $\mathrm{F}_{1}$ hybrid RF3 $\times$ PS08 was best specific combiner for all traits including grain yield plant ${ }^{-1}$.

Table 7. Contribution of lines, testers and their interactions to total variances for various yield traits in wheat under irrigated environment.

\begin{tabular}{lcccccc}
\hline Contribution (\%) & $\begin{array}{c}\text { Tillers } \\
\text { plant }^{-1}\end{array}$ & Spike length & $\begin{array}{c}\text { Grains } \\
\text { spike }^{-\mathbf{1}}\end{array}$ & $\begin{array}{c}\text { 1000-grain } \\
\text { weight }^{-}\end{array}$ & $\begin{array}{c}\text { Grain yield } \\
\text { plant }^{-\mathbf{1}}\end{array}$ & $\begin{array}{c}\text { Biological yield } \\
\text { plant }^{-1}\end{array}$ \\
\hline Lines & 26.88 & 31.31 & 31.67 & 05.95 & 15.94 & 16.44 \\
Testers & 16.60 & 09.08 & 01.40 & 59.85 & 23.95 & 33.50 \\
Lines $\times$ testers & 56.52 & 59.61 & 66.93 & 34.20 & 60.11 & 50.06 \\
\hline
\end{tabular}

yield plant ${ }^{-1}$. Several researchers (Corral (1983), Sarkar et al. (1987) and Esmail (2007)) have emphasized that preference should be given to specific crosses followed by selection in segregating generations rather than pursuing GCA by mass selection. GCA variances were significantly higher than those of SCA variances for tillers plant ${ }^{-1}$, indicating the presence of additive gene effects. The results confirm the finding of Mohammad and Chowdhry (2002), who found additive effects for numbers of tillers plant ${ }^{-1}$. Similarly, GCA variances were higher than SCA variances for spike length showing the presence of additive gene effect. Out of six lines, four (IR1, RF1, RF2, RF3) were good general combiners for tillers plant ${ }^{-1}$, grains spike ${ }^{-1}$ and grain yield plant ${ }^{-1}$. Among testers, KT10 was good general combiners for 1000-grain weight, grain yield plant ${ }^{-1}$ and biological yield plant ${ }^{-1}$, while PS08 was good combiner for spike length and grains spike ${ }^{-1}$. It is therefore suggested that inter-matting of randomly selected progenies in early segregating generation (especially
Acknowledgement: The author highly acknowledge Higher Education Commission (HEC) Pakistan for financial support through indigenous 5000 fellowship program and generous cooperation of Wheat Breeding Section, Cereal Crops Research Institute (CCRI), Pirsabak, Nowshera, Khyber Pakhtunkhwa, Pakistan.

\section{REFERENCES}

Ahmadi, J., A.A. Zali, B.Y. Samadi, A. Talaie, M.R. Channdha, and A. Saeidi. 2003. A study of combining ability and gene effect in bread wheat under drought stress conditions. Iranian J. Agric. Sci. 34:1-8.

Akbar, M., A. Rehman, M.H. Chaudhry, and M. Hussain. 1997. Prepotency judgment of diallel crosses in $F_{1}$ generation for wheat improvement. Sci. Int. (Lahore) 47:303-305. 
Akbar, M., J. Anwar, M. Hussain, M.H. Qureshi, and S. Khan 2009. Line $\times$ tester analysis in bread wheat (Triticum aestivum L.). J. Agric Res. 47:21-30.

Bhateria, S., S.P. Sood, and A. Pathania. 2006. Genetic analysis of quantitative traits across environments in linseed (Linum usitatissimum L.). Euphytica 150:185194.

Chaudhry, M.A., M.S. Akhtar, and M.T. Ahmad. 1992. Combining ability analysis for flag leaf area, yield and its components in spring wheat. Pak. J. Agric. Res. 30:1723.

Corral, L.R. 1983. Influence of competition on combining ability estimates and subsequent prediction of progeny performance in wheat (Triticum aestivum L.). Ph.D. Thesis, Oregon State University, Oregon, USA.

Esmail, R.M. 2007. Detection of genetic components through triple test cross and line $\times$ tester analysis in bread wheat. World J. Agric. Sci. 3:184-190.

Jan, M.T., P. Shah, P.A. Hollington, M.J. Khan, and Q. Sohail. 2009. Agriculture Research: Design and Analysis, A Monograph. NWFP Agric. Univ., Peshawar, Pakistan.

Jatav, M., S.K. Jatav, and V.S. Kandalkar. 2014. Combining ability and heterosis analysis of morpho-physiological characters in wheat. Ann. Plant Soil Res. 16:79-83.

Joshi, S.k., S.N. Sharma, D.L. Singhania, and R.S. Sain. 2003. Genetic analysis of yield and its component traits in spring wheat (Triticum aestivum L.). Acta Agronomica Hungarica 51:139-147.

Kempthrone, O. 1957. An introduction to genetics statistics. John Willy and Sons Inc., New York.

Khan, A.S., I. Salim, and Z. Ali. 2003. Heritability for various morphological traits in wheat. Int. J. Agric. Biol. 5:138140.

Khan, A.S., I. Khaliq, and R. Ahmad. 2010. Combining ability studies on yield related traits in wheat under normal and water stress conditions. Pak. J. Agric. Sci.47: 345-354.
Khan, I., I.H. Khalil, and N.U. Din. 2007. Genetic parameters for yield traits in wheat under irrigated and rainfed environments. S. J. Agric. Sci. 23:974-982.

Khan, M.A., M. Kashif, J. Ahmad, A.S. Khan, I. Khaliq, F. Bilquees and S. Shaukat. 2014. Sadaf- A potential donor for enhancing frequency of doubled haploids in wheat $x$ maize crossing system. Pak. J. Agri. Sci. 51:353-357.

Kruvadi, S. 1991. Heterosis study for yield and associated characters in durum wheat under upland conditions. Turrialba Pub. 4:335-338.

Larik, A.S., A.R. Mahar, and H.M.I. Hafiz. 1995. Heterosis and combining ability estimates in diallel crosses of six cultivars of spring wheat. Wheat Inform. Ser. 34:12-19.

Majeed, S., M. Sajjad, and S.H. Khan. 2011. Exploitation of non-additive gene actions of yield traits for hybrid breeding in spring wheat. J. Agric. Soc. Sci.7:131-135.

Masood, M.S., and W.E. Kronstad. 2000. Combining ability analysis over various generations in diallel crosses of bread wheat. Pak. J. Agric. Res. 16:1-4.

MINNFSAR. 2015. Agricultural statistics of Pak. Ministry of National Food Security and Research. Economic Wing, Islamabad, Pakistan.

Muhammad, N., and M.A. Chowdhry. 2002. Ability of bread wheat genotypes to combine for high yield under varying sowing conditions. J. Genet. Breed. 56:119-125.

Noorka, I.R., and J.A. Teixeira da Silva. 2014. Physical and morphological markers for adaptation of drought-tolerant wheat to arid environments. Pak. J. Agri. Sci. 51:943952.

Sarkar, D.D., O.J. Joardar, and M.Hussain. 1987. Combining ability analysis in wheat. Environ. Ecol. 5:809-810.

Sulayman, S., and N. Akguni. 2007. Combining ability and inheritance of some agronomical traits in bread wheat (Triticum aestivum L.). Ziraat Akultesi Dergisi 21:104108. 